\title{
Student Moral Quality Measurement Framework Based on Ancient Javanese Philosophy
}

\author{
Purwo Susongko*, Habibie Wilyama Dwi Sunu, Yuni Arfiani
}

Universitas Pancasakti Tegal, Indonesia

*Corresponding author. Email: purwosusongko@upstegal.ac.id

\begin{abstract}
Ancient Javanese philosophy provided a framework for measuring students' moral qualities. The moral quality of a person in Ancient Javanese philosophy is divided into three levels of consciousness namely high (Satva), medium (rajah) and low (Tamah). This research aims to analyze the needs of tests that measure moral quality and compile test points that can measure the moral quality of students based on Ancient Javanese philosophy. . This type of research is Research and Development. The object of this research is an instrument measuring the moral quality of students based on Ancient Javanese philosophy. Instrument development research design using ADDIE procedural model (Analysis, Design, Development, Implementation, Evaluation). This research is limited to the Analysis and Design stage. Pthere are all levels of consciousness (Satva,rajah and suh) have a common vision that is measuring the extent to which a person can control oneself. There are 15 indicators of 27 behavioral indicators at the satva awareness level that can be used effectively to measure students' moral qualities. Furthermore, the 15 indicators can be further developed into test points that measure the moral quality of students based on Ancient Javanese philosophy. The test items still need to be validated empirically.
\end{abstract}

Keywords: Measurement, Ancient Javanese, Quality, Moral

\section{INTRODUCTION}

Javanese philosophy is divided into three periods namely Jawadipa, Ancient Java, and New Java. Jawadipa teachings are considered to be the original teachings of Java which until now there has been no solid reference other than a book Babad Kanung [2]. The use of Tumpeng in ceremonies, pmujaan against ancestralspirits, calculation of time in the form of wuku, windu, neptu dina, and some other things are considered to be derived from The time of the Javadipa civilization. The teachings of Ancient Java in principle are the teachings of Jawadipa combined with Shiva religion and Mahayana Buddhism. Works of Philosophy in Ancient Java are quite numerous and quite comprehensive among them are Sang Hyang
Tatwajnana,SangHyang Nawa ruci and Sarasammuscaya [3]. The new Javanese teachings are the teachings of Sufi Islam combined with the teachings of Ancient Java and his book is still available completely, especially in Karaton. Surakarta and Yogyakarta.

Ancient Javanese philosophy was a philosophical system based on a spiritual approach. Spirituality in the Javanese mind is human behavior based on weakening egoism. With the weakening of human egoism, the peace of life can be formed independently of religious or cultural understanding. With the weakening of egoism, human self-control will be easier to do. Many 
studies show that good self-control will have an effect on a person's moral qualities $[5,6,7,8]$.

The concept of morality has been variously defined by philosophers and psychologists but in general the term can be interpreted as a person's or society's view of what is perceived as the highest good. Such a view is based on a set of principles, ideas, and norms used to distinguish between 'right' and

Wrong'. Although the idea of what is 'good' and what constitutes happiness has a definite cultural bias, morality generally refers to attitudes and tendencies that foster respect, responsibility, integrity and honesty. Lickona [2] argues that respect and responsibility are the two core components of morality. Morality is seen as a 'system of rules governing social interaction and social relations' of individuals in society and is based on the concepts of well-being, trust, justice. distribution and rights [11].

Humans in general determine their actions based on cognitive ability to interpret social situations. Problem reasoning, problem-solving skills, selfcontrol and adaptability are key components of the moral process. Basically self-control and moral integrity are neutral. Self-control plays an important role for moral quality only when one has a desire to have good morals. Thus without a desire, selfrecriedness and integrity have no effect on the improvement of morality[12].

A desire to have good moral qualities depends largely on the level of awareness a person has. The moral quality in the view of Ancient Javanese philosophy is strongly influenced by the quality of consciousness that a person has[13]. This is because a person's level of consciousness will affect the way of thinking and ultimately affect his speech and actions in accordance with the basic principles of the law of action in philosophy. East in general [1 4].

The level of achievement of consciousness in general according to Ancient Javanese education theory consists of three levels namely Satwa (stable and calm), Rajah (aggressive and full of motion) and Tamah ( Slow and lazy). Satva consciousness has characteristics: (1) Can control emotions, thoughts and actions; (2) Be kind, honest and in accordance with laws or norms, (3) Have tolerance, be calm, (4) have stable and unselfish intellectual abilities, (5) Have knowledge, skills,(6) Diligent meditation And always raise the spiritual level. Rajah consciousness has characteristics: (1) Easy direction, jealous, always proud of himself, (2) Have selfish nature, bossy, happy to seek attention,(3) greedy, full of ambition and worldly desires and always worried,(4) Be not serious in raising the spiritual level,(5) Be Egocentric or selfless when helping others. Suh consciousness has characteristics: (1) Be pedestal, inactive, depressed, and very selfish, (2) Be indifferent to others or even harm others, (3) Have a quick attitude angry; (4) Have a high appetite for mwill, drink, sexual intercourse[1].

Based on indicators developed quite comprehensively in the books of Ancient Javanese philosophy has the potential to be further developed into instruments that can be used in assessing Morality of students in school. The morality of students in schools should rest on the context of Indonesian national culture so that the assessment of student morality should also use the roots of the original culture of the Indonesian nation. To develop the instrument requires the study of analysis and design of tests and the development of test points that can measure the moral quality of students based on Ancient Javanese philosophy. implementation and evaluation. This research aims to analyze the needs of tests that measure moral quality and compile test points that can measure the moral quality of students based on philosophy. Ancient Java.

\section{METHOD}

This type of research isResearch and Development(15). The object of this research is an instrumentof moral quality of students based on Ancient Javanese philosophy. Rcanganinstrument development research using the procedural model ADDIE (Analysis, Design, Development, Implementation, Evaluation) (16). This research is limited to the Analysis and Design stage. There are also several stages of instrument development can be explained as follows: 


\subsection{Analysis}

This research product is an instrument that measures the moral quality of students in high school or equivalent in Indonesia. The ini test is a minimal adequacy test and is used for wide-scale purposes. In accordance with the policy of the Ministry of Education and Culture of the Republic of Indonesia, character education is one of the main objectives of education so that the development of student morality becomes the main goal. Education in Indonesia.

\subsection{Design}

The design stage, researchers began benchmarking related to the three qualities of human consciousness in accordance with the formulation of Ancient Javanese philosophy, namely the quality of satva,rajah and tamah. All three are high levels of consciousness (satva), rajah (medium)and suh (low). The three levels each have indicators. These indicators are described in detail in Rontal Sang Hyang Tatwajnana [1]. At the satva level consists of 27 indicators, at the level of rajah as many as 25 indicators while at the level of suh as many as 17 indicators.

Of all the indicators formulated from the three levels of consciousness, it can actually be concluded that all of them measure a person's level of self-control. Therefore, in the development of test points can use indicators formulated by one level only of the three levels of consciousness. In the development of test items are selected using indicator indicators that have been formulated at the satva awareness level. Of the 27 satva level awareness indicators not all of them are practical enough and easy to use to further develop into test items. In the development of test items selected only 15 of the 27 indicators are formulated as indicators of satva behavior. Table 1 here is a behavioral indicator at the satva level.

Table 1. Indicators of Human Behavior at Satva Awareness Level

\section{Satva Awareness level indicator}

1. Prajna Widagda: Capable on knowledge

2. Weruh ing yogya tan yogya: know obedience and not propriety

3. Akamulyan denyamawambek: very good behavior

4. Ahadyan tengen tan gurugada: although it has strength but never happens rude

5. Tan babkujar: not carelessly issue words

6. Bhakti: Respecting anyone

7. Tonanduga-duga: iklas

8. Asih ta ya ring kasyasih: compassionate to those who suffer

9. Anumeda ring inadina, tuning sungsut: giving comfort to the dina and grieve

10. Satya bhakti: be faithful and respectful

11. Arumpating Alana: Crippling all inner vices 
12. Somya wacanana: soft speech

13. Aten ya ngucap literature: earnest in carrying out sacred teachings

14. Kamuni wacanana utsahangusing for pangrawuh kasayamyagjnanan: always pursue all good things, namely true and useful knowledge

15. Tan pamali nghela: tireless in doing good

16. Tan keneng sungsut: no quick to grieve when hit by an accident

17. Kwala bungah patingalanna: always happy heart, means always who has a grateful heart

18. Sapolahna mangdadyaken arsa ring sang tumingal: whatever he does makes happy people who look

19. Sabdana mangdadyaken because manohara ring the mangrengo: his speech is pleasant for those who hear

20. Mahardika understbekana mangdadyaken tripti paritusta ring citta ning para: his policy of behavior made calm and happy crowds

21. Masor ta ya ring abhipraya: not greedy on desire

22. Mango kociwaho: does not disappoint his behavior

23. Tan kepomahar sukhambekning para: unaffected by the judgment of others

24. Tatanahangkara: not at will itself

25. Tan moha denyamawa prawerti: not confused in acting

26. Kewala bungah santa lilang: always happy and calm

27. Atning nirwarana tan patalutuh, atah pinaka jnanana, beautiful patingalanna: has a clean heart without stains, so it is very unsightly

\section{RESULTS AND DISCUSSION}

Based on 27 indikator of the Ancient Javanese Book Rontal Sang Hyang Tatwajnana, selected 15

indicators that are considered easy and practical to be further developed into test points. These indicators are described in Table 2.

Table 2: Indicators of Student Moral Quality Test Based on Ancient Javanese Philosophy

\begin{tabular}{|c|l|}
\hline Indicators & Questions Code \\
\hline 1. Weruh ing yogya tan yogya: know obedience and not propriety & 1 \\
\hline 2. Ahadyan tengen tan gurugada: although it has strength but never happens rude & 2 \\
\hline 3. Tan babkujar: not carelessly issue words & 3 \\
\hline
\end{tabular}




\begin{tabular}{|l|l|}
\hline 4. $\quad$ Bhakti: Respecting anyone & 4 \\
\hline 5. Asih ta ya ring kasyasih: compassionate to those who suffer & 5 \\
\hline 6. Anumeda ring inadina, tuning sungsut: giving comfort to the dina and grieve & 6 \\
\hline 7. Satya bhakti: be faithful and respectful & 7 \\
\hline 8. Tan pamali nghela: tireless in doing good & 8 \\
\hline 9. Tan keneng sungsut: no quick to grieve when hit by an accident & 9 \\
\hline 10. Tan kepomahar sukhambekning para: unaffected by the judgment of others & 10 \\
\hline 11. Tonanduga-duga: iklas & 11 \\
\hline 12. Masor ta ya ring abhipraya: not greedy on desire & 12 \\
\hline 13. Kwala bungah patingalanna: always happy heart, means always who has a grateful & 13 \\
\hline 14. Tatanahangkara: not at will itself & 14 \\
\hline 15. Arumpating Alana: Crippling all inner vices & 15 \\
\hline
\end{tabular}

Furthermore, all these indicators become references in the development of moral quality tests of students. In principle the test is built by providing a case that requires a person's moral qualities to solve it. Furthermore, after the completion is known, students are asked to give their consent by choosing the option of strongly agreeing, agreeing and disagreeing. The test used uses the Likert scale with three answer options: strongly agree (SS), Agree (S) and Disagree (TS).
Each statement in an item is made in two types each positive statement and a negative statement. In a positive statement, if the student chooses an answer strongly agree to get a score of 3 , when choosing an answer agree to get a score of 2 and when choosing an answer do not agree get a score of 1 . Conversely, in a negative statement, if the student chooses an answer strongly agrees to get a score of 1 , when choosing an answer agree to get a score of 2 and when choosing an answer not Agree to get a score of 3. Testitems can be seen in table 3 below.

Table 3. Details of Student Moral Quality Test Based on Ancient Javanese Philosophy

\begin{tabular}{|c|c|c|c|c|c|}
\hline No. & Statement & SS & $S$ & TS & Key \\
\hline 1 & $\begin{array}{l}\text { Rani is grieving that her parents died. At the same time Rani's best friend, Toni } \\
\text { was in need of help so he borrowed money from Rani. Do you agree with Toni's } \\
\text { attitude to Rani? }\end{array}$ & & & & - \\
\hline 2. & $\begin{array}{l}\text { Jack Ma is a professional marketing director, once he had an employee named } \\
\text { Sinta. Sinta is currently working unsannionally until it does not close the } \\
\text { company's product marketing targets. But finally Jack Ma did not fire Sinta with } \\
\text { a record in } 3 \text { months could close the marketing target. Do you agree with what } \\
\text { Jack Ma did to Sinta? }\end{array}$ & & & & + \\
\hline 3 & $\begin{array}{l}\text { Fajar is a teacher, he does not realize if playing social media carried away by the } \\
\text { flow of hoax information. And often sharing hoax information and often arguing } \\
\text { with hate speech with colleagues who are not in line. Do you agree with the } \\
\text { dawn? }\end{array}$ & & & & - \\
\hline 4. & $\begin{array}{l}\text { Dani is a Student,she is knownas a friendly student and has great respect for her } \\
\text { teacher. But actually he behaved like that because he had a certain intention to } \\
\text { the teacher in order to get a good grade. Do you agree with Dani'sattitude? }\end{array}$ & & & & - \\
\hline
\end{tabular}




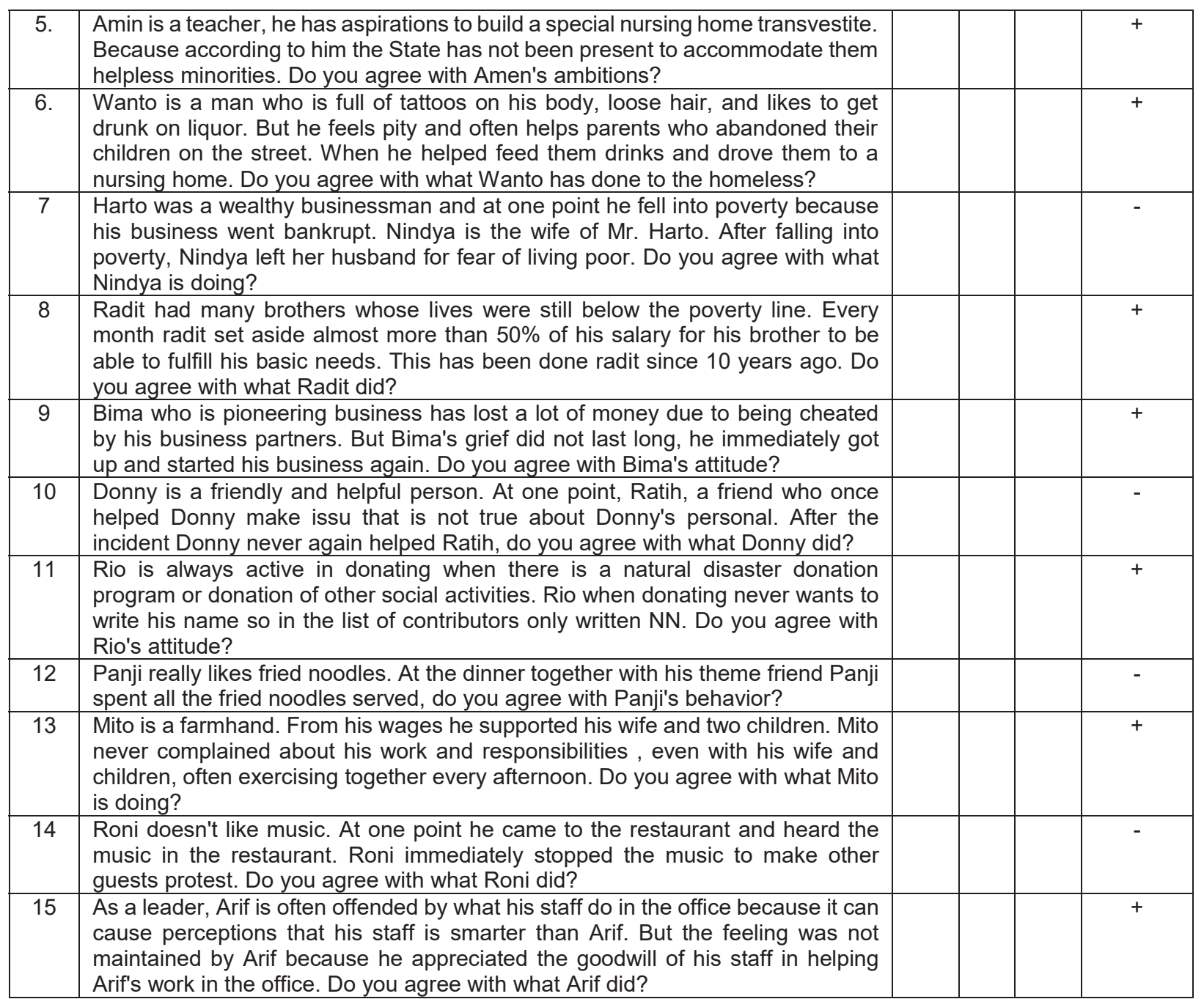

Users of this test are expected to be high school students or equivalent. But the test can also be used for students in college. This is because the cases stated in each statement will be optimally understood well by students who are at least in high school or equivalent. The resulting test items still need to be tested empirically to measure the validity of the test items that have been compiled. When using Rasch modeling it takes a minimum of 100 respondents while when using Item Response Theory modeling it takes a minimum of 300 respondents[17,18].

\section{CONCLUSION}

Ancient Javanese philosophy provided a framework for measuring students' moral qualities. The moral quality of a person in Ancient Javanese philosophy is divided into three levels of consciousness namely high (Satva), medium (rajah) and low (Tamah). Each level has behavioral indicators and and indicators at all levels have a common vision that is measuring the extent to which a person can control themselves. There are 15 indicators of 27 behavioral indicators at the satva awareness level that can be used effectively to improve students' moral qualities. Furthermore, the 15 indicators can be further developed into test points that measure the moral quality of students based on Ancient Javanese 
philosophy. The test items still need to be validated empirically.

\section{REFERENCES}

[1]. Shashangka, D., \& Murti, S. (2015). Ancient Javanese science: Sanghyang Tattwajñāna nirmala Nawaruci. Dolphin.

[2]. Sigit Wibowo \& Eko Teguh Widodo (2016). History of Javanese travel (230 BC-1292). Jakarta: Jawa Kanung Foundation

[3]. Anand Krisna. (2015). Dvipantara dharma literature. Jakarta: Centre for Vedic \& Dharmic Studies

[4]. Susongko, P. (2019). Construction of Education Theory Based on Ancient Javanese Philosophy (Study of Documentary Analysis Based on the Book of Sang Hyang Tatwa Jnana and Sang Hyang Nawa Ruci). Horizons: Journal of Education, 13(1), 73-88.

[5]. Wikström, P. O. H., \& Svensson, R. (2010). When does self-control matter? The interaction between morality and self-control in crime causation. European Journal of Criminology, 7(5), 395-410.

[6]. Svensson, R., Pauwels, L., \& Weerman, F.M. (2010). Does the effect of self-control on adolescent offending vary by level of morality? A test in three countries. Criminal Justice and Behavior, 37(6), 732-743.

[7]. Bertok, E., \& Meško, G. (2013). Self-Control and Morality in Slovenian Primary and Secondary School Sample: The Results of YouPrev Study. Varstvoslovje: Journal of Criminal Justice \& Security, 15(4).

[8]. Barton-Crosby, J., \& Hirtenlehner, H. (2020). The Role of Morality and Self-Control in Conditioning the Criminogenic Effect of

[18]. Hambleton, R. K., \& Swaminathan, H. (2013). Item response theory: Principles and applicat ions. Springer Science \& Business Media.
Provocation. A Partial Test of Situational Action Theory. Deviant Behavior, 1-22.

[9]. Kaur, S. (2015). Moral values in education. IOSR Journal of Humanities and Social Science, 20(3), 21-26.

[10]. Lickona, T. (2009). Educating for character: How our schools can teach respect and responsibility. Bantam.

[11]. Smetana, J. G. (2018). Becoming moral: Introduction to the special issue on early moral development. Human Development, 61(4-5), 209-213.

[12]. Nucci, L. P., Narváez, D., \& Krettenauer, T. (Eds.). (2014). Handbook of moral and character education. New York: Routledge.

[13]. Susongko, P. (2021). Taxonomy of Educational Objectives in the Perspective of the Old Java Educational Theory: an Application to Holistic Education.

[14]. Shenga, S., Jha, A., \& Mishra, S. N. (2015). Himalayan Eco-Philosophy. Research Journal of Humanities and Social Sciences, 6(3), 191-196.

[15]. Gall, M. D., Gall, J. P., \& Borg, W. R. (2014). Applying educational research: How to read, do, and use research to solve problems of practice. Pearson Higher Ed.

[16]. Molenda, M. (2015). In search of the elusive ADDIE model. Performance Improvement, $54(2), 40-42$.

[17]. Cecilio-Fernandes, D., Medema, H., Collares, C. F., Schuwirth, L., Cohen-Schotanus, J., \& Tio, R. A. (2017). Comparison of formula and numberright scoring in undergraduate medical training: a Rasch model analysis. BMC medical education, 17(1), 1-9. 